\title{
Wiedza o języku jako klucz do polityki tożsamościowej Kaszubów. Artykuł recenzyjny książki Adeli Kożyczkowskiej: Kaszubszczyzna. Pedagogicznie o języku i tożsamości. \\ Gdańsk 2019, Wydawnictwo Uniwersytetu Gdańskiego, ss. 276
}

Kilka tygodni po wydaniu przez Wydawnictwo Uniwersytetu Gdańskiego książki Adeli Kożyczkowskiej Kaszubszczyzna. Pedagogicznie o języku i tożsamości, na internetowym portalu „Skra - pjismjono wo kùlturze” zamieściłem „na gorąco” pisaną prasową recenzję tej publikacji, zatytułowaną Walka o tożsamość, znaki i znaczenia. Wracam do tego tematu z perspektywy kilkunastu miesięcy obcowania z tezami zawartymi w pracy Adeli Kożyczkowskiej, przekonany, że książka tej gdańskiej pedagożki otwiera pola do nowych interpretacji „wpływu pewnych koncepcji, idei, wyborów identyfikacyjnych i tożsamościowych na kondycję ludzką", by używając słów Jolanty Tambor umieszczonych na 4. stronie okładki książki, wyrazić najpełniej własną myśl.

Na samym początku należy ustalić, czym dla Adeli Kożyczkowskiej jest pojęcie „kaszubszczyzna” (kasz.: kaszëbjizna). W badaniach językoznawczych pojęcie to oznacza wyłącznie język kaszubski i/lub jego odmiany: kaszubszczyzna mówiona, kaszubszczyzna literacka, kaszubszczyzna dialektalna (Breza, 2001; Treder, 2002). Określenie to funkcjonuje więc podobnie jak pojęcie „polszczyzna” czy „niemczyzna”. W nieco bardziej współczesnych badaniach, w dziedzinach takich jak socjolingwistyka, socjologia i literaturoznawstwo, pojęcie „kaszubszczyzna” pozostaje synonimem pojęcia język kaszubski (Kuik-Kalinowska, 2011; Mazurek, 2010; Wicherkiewicz, 2014). W dyskursie społeczno-politycznym, niektórzy jego uczestnicy nadają temu pojęciu nieco szersze znaczenie: „kaszubsczyzna/kaszëbjizna” bywa rozumiana przez nich jako język i kultura Kaszubów (Jabłoński, 2013/2018). Adela Kożyczkowska proponuje, byśmy rozumieli „kaszubszczyznę” jako - jak sama zaznacza „egzemplifikację pewnego projektu kulturowego" (s. 15). Punktem wyjścia do 
tego projektu był oczywiście język kaszubski i to już u jego zarania, co wiąże się z osobą Floriana Ceynowy, dziewiętnastowiecznego budziciela Kaszubów, jednak ów język został niejako obudowany praktykami kulturowymi, których celem było i jest budowanie tożsamości. „Kaszubszczyzna” Adeli Kożyczkowskiej jest zatem całą przestrzenią kulturową Kaszub. Tę przestrzeń, jak zauważa gdańska pedagożka, konstruują dwa główne „projekty intelektualne” koncentrujące się na dwóch tożsamościach Kaszubów, które autorka proponuje nazywać: „polonocentryczną" i „kaszubocentryczną” (s. 11 i inne).

Z każdą kolejną stroną swojej pracy Adela Kożyczkowska, zatrudniona na Wydziale Nauk Społecznych Uniwersytetu Gdańskiego, w Instytucie Pedagogiki, gdzie współtworzy Zakład Pedagogiki Ogólnej, udowadnia, że nie ma przesady w przyjętej przez nią tezie, iż kaszubszczyzna to „permanentna pedagogia, czyli sfera, w której toczy się walka (?), gra (?) o znaki i znaczenia (...), o tożsamość" (s. 16). Wśród wielu założeń, które A. Kożyczkowska poczyniła, przystępując do opisania swoich badań (o których pisze we wstępie i rozdziale 1 . poświęconym przyjętej metodologii), jest i takie, by czytelnik traktował przytoczone pod konkretnym nazwiskiem, słowa i wypowiedzi jako „stanowiska teoretyczne”. Chodzi o to, by nie utożsamiać ich z konkretną osobą, lecz „autorem, który mówi zawsze z pola jakiejś hegemonii”. Poprzez przyjęcie takiej perspektywy w tekście książki swoje poglądy odnajdą z łatwości zarówno te osoby, które były uczestnikami konkretnych „praktyk kulturowych", jak również ci czytelnicy, którzy chcą się utożsamiać z jakąś „nieuosobioną" ideą.

Należy zwrócić uwagę, że książka A. Kożyczkowskiej jest syntezą całego cyklu badań i publikacji tej autorki pod wspólnym tytułem Kaszubszczyzna jako wiedza: język, edukacja, kultura i obywatelskość. Wcześniej przepracowane przez badaczkę pojmowanie zagadnienia kaszubszczyzny jako kultury, jako praktyki językowej i edukacyjnej oraz jako tożsamości sprawia, że tekst książki jest klarowny, a tezy autorki o politycznym organizowaniu wiedzy i doświadczeń w kontekście projektów „kaszubocentrycznego” oraz „polonocentrycznego" są spójne i dobrze rozwinięte. Nie będzie to nadużycie, jeśli dołączymy do tych czytelników, którzy odnajdują w tych tezach ujęcie charakterystyczne dla tradycji badań postkolonialnych. Można jedynie żałować, że niewystarczająca znajomość kultury niemieckiej - co autorka sama przyznaje - była przyczyną, dla której zrezygnowała z badania relacji kaszubsko-niemieckich, a tym samym „niemieckocentrycznej” tożsamości części Kaszubów.

Adela Kożyczkowska skupia się więc na walce prowadzonej przez dwa - jak to opisała - „intelektualne modele kaszubszczyzny”. Jeden z nich jest konse- 
kwentnie zamknięty na różnice kulturowe i, cytując autorkę, „wynika z lęku przyznania się do własnego rozróżnienia od większości - w tym przypadku - polskiej” (s. 250). Drugi jest jak najbardziej otwarty na kulturowe różnice, gdyż towarzyszy mu - zdaniem badaczki - przekonanie, iż: „tylko uznając różnicę, można uznać wielokulturową naturę świata” oraz „świadomie zabiegać o własną tożsamość etniczną" (ss. 250-251). Autorka, jako że rzeczywistość kaszubskiego świata zna nie tylko z literatury, ale przede wszystkim z własnych doświadczeń, swój wywód prowadzi ze znawstwem, by sformułować wniosek, iż kaszubocentryzm i polonocentryzm to w gruncie rzeczy konfrontacyjne stanowiska teoretyczne, które stanowią dwa odrębne systemy wiedzy.

Gdańska pedagożka przedstawia swoje teorie bez emocji, które zwykle towarzyszą omawianiu różnych kaszubskich tożsamości, a przez to, w większości przypadków, sięga sedna przeciwstawnych postaw kaszubskich elit - ich przyczyn i skutków. Tekst jest znakomitą syntezą zarówno jednego z dyskursów - rozpoczętego przez Floriana Ceynowę, a kontynuowanego obecnie przez środowisko stowarzyszenia Kaszëbskô Jednota, jak i drugiego - zapoczątkowanego przez Hieronima Derdowskiego, a współcześnie odbijającego się w zwierciadle Ustawy o mniejszościach narodowych i etnicznych oraz o języku regionalnym. Wydaje się, że tylko w jednym miejscu, takie jest moje zdanie, autorka nie trafia ze swoją interpretacją. Chodzi o ten fragment książki, w którym A. Kożyczkowska wysuwa tezę, iż uchwała II Kongresu Kaszubskiego (odbył się w 1992 roku w Gdańsku), a w szczególności wystąpienie Donalda Tuska na tymże Kongresie, który przekonywał, by Kaszubi zwiększyli swą współodpowiedzialność za los ogółu obywateli, były podstawą programu ideowego „Òdrodë” - grupy młodej inteligencji skupionej wokół pisma o tym samym tytule. Jednak nie miejsce tu na polemikę, choć moja reakcja - nie tylko badacza, ale także kaszubskiego aktywisty - może świadczyć o tym, że książka ma szansę wywołać polemiczne głosy.

Adela Kożyczkowska była przez lata bliską współpracownicą Kazimierza Kossak-Główczewskiego, a dziś jest samodzielną badaczką wielokulturowości, jako istotnego problemu społecznego i edukacyjnego. W książce Kaszubszczyzna. Pedagogicznie o języku i tożsamości dzieli się syntetycznym spojrzeniem na ważny i wciąż aktualny problem miejsca kaszubszczyzny w zmieniającej się rzeczywistości, którą cechuje walka o znaki i znaczenia. Symbolicznym tego wyrazem może być pierwsza strona okładki. Kilka fotografii mężczyzn w mundurach różnych armii, a także rodzin zgromadzonych na religijnych rytuałach chrztu i komunii - uświadamiają, jak skomplikowana to rzeczywistość na pograniczu kultur. Adela Kożyczkow- 
ska przyznaje, że swoją książką chce włączyć dyskurs tożsamości kaszubskiej w przestrzeń pedagogiki międzykulturowej. To zadanie omawiana książka spełnia, na dowód czego można przytoczyć opinię, którą wyraziła Hllžbjeta (Liza) Waltherowa z Instytutu Sorabistyki Uniwersytetu w Lipsku. W mediach społecznościowych, wspominając o przygotowywanej przez siebie recenzji pracy Adeli Kożyczkowskiej, pod postem zamieszczonym przez piszącego te słowa, a zaczynającym się od zdania „Szósta z siedmiu ważnych dla mnie książek”, L. Waltherowa napisała: „Ta książka bardzo pomogła mi dużo zrozumieć w kwestii kaszubskiej, a także uświadomić wiele łużyckich problemów i potencjalnych rozwiązań" (https://www.facebook.com/photo. php?fbid $=1596057393880859 \&$ set $=$ a $.129746267178653 \&$ type $=3 \&$ theater 30.05.2020 r.).

Wielokulturowość to wynik wielu polityk, w tym także polityki edukacyjnej. Autorka książki Kaszubszczyzna. Pedagogicznie o języku i tożsamości, będąc tego świadoma, daje czytelnikowi kompendium, którego nie należy rozważać w kontekście jednego konkretnego przedmiotu czy nawet grupy przedmiotów. Adela Kożyczkowska zaprasza nas do znacznie szerszej pedagogicznej refleksji nad wyborami tożsamościowymi zbiorowości, ich społecznym charakterem i praktykami będącymi projektami intelektualnymi (aktywistów, badaczy, myślicieli). Wiedza, będąca wytworem tych kulturowych zmagań, pozwala utrzymać władzę nad człowiekiem, który zgadza się na przyjęcie tych lub innych znaków i ich znaczeń, a przez to buduje narrację o świecie - czym ten świat jest i jaki powinien być. W przypadku świata kaszubskiego gdańska pedagożka zauważa, iż polityka tożsamościowa zmierzać może w kierunku mniejszościowej wspólnoty o etnicznym charakterze i silnych zobowiązaniach obywatelskich jej członków wobec państwa, z którym Kaszubi pozostają w ścisłych związkach. By to osiągnąć, potrzebny jest taki projekt intelektualny, który pozwoli wyjść poza dotychczasowe dyskursy, co możliwe jest wtedy, kiedy elity staną się otwarte na różnicę kulturową.

\section{Bibliografia}

Breza, E. 2001. Kaszubszczyzna - Kaszëbizna. Opole: UO.

Jabłoński, A. 2013. Kaszubi. Wspólnota narodowa. Gdynia: Wydawnictwo Region.

Jabłoński, A. 2019. Walka o tożsamość. Znaki i znaczenia, Skra - pjismjono wo kùlturze, https://pismiono.com/recenzejo-walka-o-tozsamosc-znaki-i-znaczenia/. 
Kuik-Kalinowska, A. 2011. Tatczëzna. Literackie przestrzenie Kaszub. Gdańsk - Słupsk: Instytut Kaszubski, Akademia Pomorska.

Mazurek, M. 2010. Język - przestrzeń - pochodzenie. Analiza tożsamości kaszubskiej. Gdańsk: Instytut Kaszubski.

Treder, J. 2002. Język kaszubski. Poradnik encyklopedyczny. Gdańsk: UG, Oficyna Czec.

Wicherkiewicz, T. 2014. Regionalne języki kolateralne Europy-porównawcze studia przypadku polityki językowej. Poznań: Wydawnictwo Rys. 